THE KURUME MEDICAL JOURNAL Vol. 15, No. 3,1968

\title{
A NEW DOUBLE MEDICATION METHOD FOR THE TREATMENT OF ALCOHOLISM USING THE DRUG CYANAMIDE
}

\author{
HIROSHI MUKASA AND KATSUYOSHI ARIKAWA \\ Department of Neuropsychiatry, Kurume University \\ School of Medicine, Kurume, Japan
}

(Received for publication October 5, 1968)

\section{INTRODUCTION}

Since complete abstinence is very difficult for alcoholics, we must try to find some other effective therapy. The effectiveness of Calcium Cyanamide for the treatment of alcoholism has been long recognized. An antialcoholic drug Cyanamide is shown in Table 1 . We ascertained that the alcohol detaining ef fect of Calcium Cyanamide was found after being transformed into Cyanamide by acid in the stomach.

TABLE 1

\begin{tabular}{c} 
Cyanamide \\
$\mathrm{HN}=\mathrm{C}=\mathrm{NH}$ \\
$\left(\mathrm{CH}_{2} \mathrm{~N}_{2}=42.04\right)$ \\
melting point $44-46{ }^{\circ} \mathrm{C}$ \\
$\mathrm{CaCN}_{2}+2 \mathrm{HCl} \stackrel{\mathrm{CaCl}_{2}+\mathrm{HN}=\mathrm{C}=\mathrm{NH}}{\left(\begin{array}{l}\text { Calcium } \\
\text { Cyanamide }\end{array}\right)\left(\begin{array}{c}\mathrm{Hydrochloric} \\
\text { acid }\end{array}\right) \quad(\text { Cyanamide })}$ \\
\hline
\end{tabular}

After further experiments, Cyanamide was proved to have many merits in the form of a stable solution for oral use ${ }^{4)}{ }^{5)}$.

Cyanamide occurs in white, odorless, needle-shaped crystal. Inhalation or ingestion of Cyanamide followed by drinking of an alcoholic bevarage is known to cause a syndrome characterized by intense flushing, rapid pulse, a panting respiration, and a perception of the tast and smell of acetaldehyde in the subject's exhaled breath. The syndrome generally subsides in a few hours and the subject returnes to normal usually within 24 hours. The reason for these reactions is that Cyanamide inhibits one or more of the enzymes required for oxidation of acetaldehyde formed from the alcohol. It is the accumulation of acetaldehyde and the altered vascular reaction to it that brings about the effects characterizing the syndrome.

Cyanamide has sure and prompt antialcoholic effects without producing any 
harmful reaction and can be used in a simple manner. The drug has the advantage over Antabuse of lesser toxicity and better tolerance. Previous studies by us have confirmed the efficacy of the substance in sensitizing alcoholics to alcohol. However, clinical evalution for curative powers of the drug has been made difficult because many subjects are unreliable and do not take the medication as prescribed. In an attempt to overcome this difficulty we devised a new technique for administering the drug which we have called the double medication method. This study was conducted for 6 years and involved 330 patients. We have attempted in this study to confirm the efficacy of Cyanamide in the treatment of alcoholism using a new method for administering the drug.

\section{MATERIALS AND METHODS}

Three hundred thirty patients were selected for the study. All were treated as out patients with the exception of 82 who had to be initially hospitalized for such disorders as alcoholic psychoses or organic disease.

TABLE 2

Alcoholics

\begin{tabular}{lc}
\hline Occupation & Clinical Case \\
\hline Employees of company & 85 \\
Public Officials & 74 \\
Farmers & 70 \\
Merchants & 66 \\
Others & 35 \\
\hline & 330 \\
\hline
\end{tabular}

The alcoholics were engaged in occupations as shown in Table 2. The majority were considered breadwinners in their familly. In age, they ranged from 20 to over 70, as shown in Table 3. The largest number was in the 30 to 50 years age group.

TABLE 3

Alcoholics

\begin{tabular}{|c|c|}
\hline Difference by Age & Clinical Case \\
\hline $20-29 y$ & 49 \\
\hline $30-39 y$ & 112 \\
\hline $40-49 y$ & 92 \\
\hline $50-59 y$ & 55 \\
\hline $60-69 y$ & 18 \\
\hline \multirow[t]{2}{*}{$70-79 y$} & 4 \\
\hline & 330 \\
\hline
\end{tabular}


TABLE 4

Special therapy for alcoholism

- double medication method -

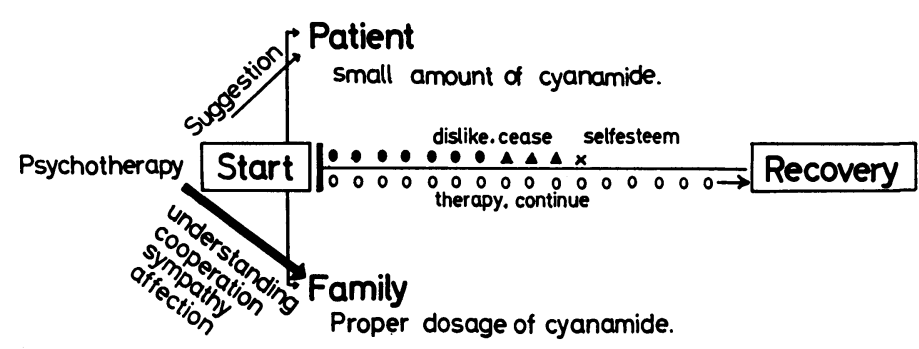

Table 4 demonstrates the double medication technique and the families role, that is, in addition to the prescription for a patient himself, the medicine is administered unawares to him through the family. Accordingly, while to a patient himself a small amount of Cyanamide $(5-10 \mathrm{mg})$ can be given, the proper dosage of Cyanamide is administered to the patient without his knowledge. Since Cyanamide is tasteless and odorless compound and can be added to any food, the families had little difficulty administering the drug. Moreover, as Cyanamide is much safer than Antabuse ${ }^{1)}{ }^{4)}{ }^{10}$ or fertilizer nitrolime ${ }^{6}$, the patient's alcohol tolerance can be reduced safely according to the amount of Cyanamide administered.

TABLE 5

\begin{tabular}{|c|c|}
\hline $\begin{array}{l}\text { Administrative Amout } \\
\text { of Cyanamide }\end{array}$ & Clinical Case \\
\hline $10 \mathrm{mg}$ & ...... \\
\hline $15 \mathrm{mg}$ & … 35 \\
\hline $20 \mathrm{mg} \ldots \ldots \ldots \ldots \ldots . . . . . .$. & .... 95 \\
\hline $25 \mathrm{mg}$ & …. 76 \\
\hline $30 \mathrm{mg} \ldots \ldots \ldots \ldots \ldots . . . . .$. & ..... 79 \\
\hline $40 \mathrm{mg}$ & $\cdots \cdots \cdot 21$ \\
\hline \multicolumn{2}{|c|}{$50 \mathrm{mg} \quad \ldots \ldots \ldots \ldots \cdots \cdots \cdots \cdots \cdots \cdots \cdots \cdots \cdots \cdots$} \\
\hline & 330 \\
\hline
\end{tabular}

The proper dose of Cyanamide differs with individuals ranging from 10 to $50 \mathrm{mg}$ per day, as shown in Table 5. The proper dose was that at which the subject became a moderate drinker. There were many cases in which the dosage was maintained between 20 to 30 milligrams so that the patients would become moderate drinker. A moderate drinker was defined as one whose daily dosage was not greater than 100-200 milliliter of Sake with a $15 \%$ alcohol content. In addition to the drug therapy, each patient and family were given some psychotherapy. An attempt was made to increase the patient's selfesteem; he was 
also encouraged to attempt to overcome his difficulties alone. The family was instructed on the difficulties of the disease in an attempt to increase their understanding and cooperation, and provide a more sympathetic attitude.

With this method the patient can remain a moderate drinker even if he stops taking medicine. This condition must be maintained by his family until his addiction disappears completely.

\section{RESULTS}

The results of the study is shown in Table 6 and 7. Table 6 shows the

TABLE 6

Term of treatment (Continuation)

\begin{tabular}{|c|c|c|}
\hline \multirow[b]{2}{*}{ Term } & \multicolumn{2}{|c|}{ Medication } \\
\hline & $\begin{array}{l}\text { through the } \\
\text { families }\end{array}$ & $\begin{array}{l}\text { patients } \\
\text { themselves }\end{array}$ \\
\hline over $1 \mathrm{M}$. & 38 cases & 16 cases \\
\hline over $6 \mathrm{M}$. & 30 & 0 \\
\hline over $1 \mathrm{Y}$. & 36 & 0 \\
\hline over $2 \mathrm{Y}$. & 32 & 0 \\
\hline over $3 \mathrm{Y}$. & 23 & 0 \\
\hline over $4 \mathrm{Y}$. & 13 & 0 \\
\hline over $5 \mathrm{Y}$. & 6 & 0 \\
\hline $6-7 \mathrm{Y}$ & 2 & 0 \\
\hline & 180 & \\
\hline
\end{tabular}

term of treatment ranged from one month to 6 years. In 190 cases the families are still administering the medication. These 180 cases can be considered social cures. That is, these patients are now moderate drinkers. However, only 16 of these 180 patients are still taking medication themselves. From this, it can be concluded that alcoholic patients will take medication only for a short time

TABLE 7

Term of treatment (Discontinued)

\begin{tabular}{|c|c|c|c|c|c|}
\hline \multirow[b]{2}{*}{ Term } & \multicolumn{2}{|c|}{ Discontinued } & \multicolumn{3}{|c|}{ Results } \\
\hline & $\begin{array}{l}\text { though the } \\
\text { families }\end{array}$ & $\begin{array}{l}\text { patients } \\
\text { themselves }\end{array}$ & abstinence & $\begin{array}{l}\text { ured } \\
\text { moderate drinker }\end{array}$ & not cured \\
\hline within $6 \mathrm{M}$. & 70 cases & 150 cases & - & - & 70 cases \\
\hline within $1 \mathrm{Y}$. & 22 & 0 & 7 cases & 15 cases & \\
\hline within $2 \mathrm{Y}$. & 21 & 0 & 10 & 11 & \\
\hline within $3 \mathrm{Y}$. & 23 & 0 & 13 & 10 & \\
\hline within $4 \mathrm{Y}$. & 6 & 0 & 4 & 2 & \\
\hline within $5 \mathrm{Y}$. & 5 & 0 & 4 & 1 & \\
\hline within $6 \mathrm{Y}$. & 3 & 0 & 2 & 1 & \\
\hline & 150 & & 40 & 40 & 70 \\
\hline
\end{tabular}


while the family will continue until they consider the patient cured. Table VII shows that in 150 patients the treatment has been discontinued by the family at varying times. In 70 subjects the therapy was discontinued within 6 months. In these 70 cases it is unlikely a cure was effected, in view of the short duration of the medication. The familie's lack of understanding on the treatment might account for the poor results in these 70 patients. However, in the remaining 80 cases it is assumed that some degree of cure was effected since the families continued the treatment for such long periods. It also can be assumed that some families discontinued the medication because they considered the subjects cured. Also in 40 of the 150 cases which discontinued the medication; the families did so because the subjects stopped drinking alcohol and thereby had no need for the medication.

TABLE 8

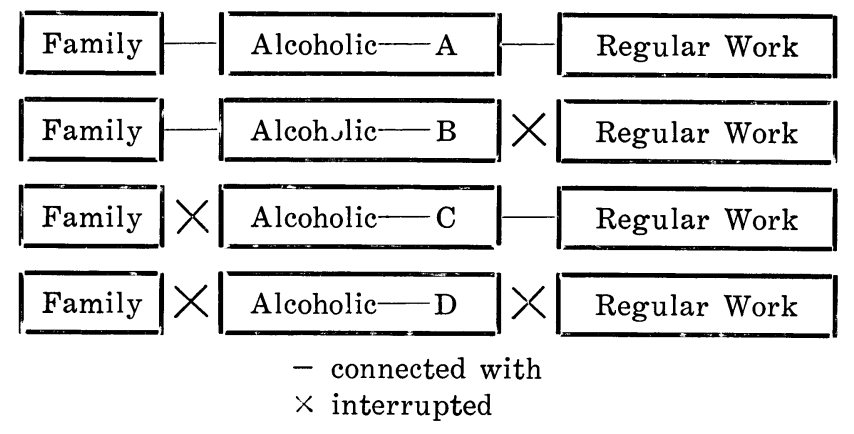

Table 8 demonstrates the prognosis for the three types of subjects seen in this study, using the double medication technique. The best result can be expected in type A group who are still connected with their families and work. In type B the prognosis is not as good as type $A$ but the double medication technique is still applicable. In type C \& D it is not possible to use the double medication technique. An obvious advantage of this technique is that it gets the family involved and increases their understanding of the illness.

\section{DISCUSSION}

There are antialcoholic drugs ${ }^{13)}{ }^{4)}{ }^{10}$ ) as shown in Table 9. Generally

TABLE 9

\begin{tabular}{lll}
\multicolumn{3}{c}{ Antialcoholic drug } \\
\hline Antabuse & 1948 & Jacobsen \\
CaCN $_{2}=$ nitrolime & 1956 & Usuba \\
Temposil (Dipsan) & 1956 & Ferguson \\
Cyanamide & 1959 & Mukasa \\
\hline
\end{tabular}


speaking, the antialcoholic drug therapy employed heretofore may be successful so long as the patient is making use of drugs, but once he ceases to take medicine because of his dislike for it, a chance of recurrence can be expected to come.

The special therapy for alcoholism adopted by Mukasa 7) 8) 9) consists essentially of the double medication of Cyanamide. In this way, a good chance for a patient to overcome his addiction offers itself.

Of great importance is that the therapist exhibits psychotherapy to both the patient and his family before treatment. The patient must be by all means led to rise his selfesteem as if he felt he could have overcome his addiction for himself. While doing the psychotherapy full of suggestions fitting to this purpose to the patient, one must carry on a more satisfactory psychotherapy to his family to make them act in close cooperation with the patient.

Under this kind of therapy, there is no need for the patient to receive hospital treatment. Even if it is necessary, hospital treatment can be probably schortend within a few weeks. In other words whenever the treatment is in condition to practice the double medication method among his family, the patient can be given permission to leave hospital at once.

Through this therapy the patient is able to return to a healthy life and at the same time the family dynamic takes a favorable turn.

\section{SUMMARY}

Three hundred and thirty alcoholic patients were treated over a 6 year period with the drug Cyanamide using a new method of administering the drug called the double medication technique in which the family administers the drug without the patient's knowledge.

One hundred and eighty patients still continued to take the medication and are considered cured by their families and are now able to function well.

Psychotherapy involving the families was an useful adjunct to the drug therapy.

The prognosis for cure is better if the patient can be treated while he is still living with his family and working at his job.

The efficacy of using Cyanamide in the treatment of alcoholism using the double medication technique is proven with this study.

The drug Cyanamide using in this study was provided by the Yoshitomi Pharmaceutical Company of Japan.

\section{REFERENCES}

1) Ferguson, J. K. W. : A new drug for the treatment of alcoholism. Canad. M. A. J., 74, 793, 1956. 
2) HALD, J. \& JACOBSEN, E. : A drug sensitizing the organism to ethylalcohol. Lancet, 255, 1001, 1948.

3) Lemere, F. : Treatment of alcoholism. IV World Congress of Psychiatry, Madrid, I. C. S., 117, 278, 1966.

4) Mukasa, H. : Clinical study on the antialcoholic action of Cyanamide (1). Kurume Med. J. Associat. 22, 1632, 1959.

5 ) Mukasa, H. : Clinical study on the antialcoholic action of Cyanamide (II). Clinical Psychiatry, 2, 23, 1960.

6 ) Mukasa, H. : Studies on the physiological antialcoholic effects of Cyanamide and its clinical application. Psychiatr. Neurol. Jap., 64, 469, 1962.

7) Mukasa, H., Ichinara, T. \& Eto, A. : A new treatment of alcoholism with Cyanamide $\left(\mathrm{H}_{2} \mathrm{NCN}\right)$. Kurume Med. J. Japan, 11, 96, 1964.

8 ) Mukasa, H. : Clinical studies on a new antialcoholic treatment using the drug Cyanamide. Janan. J. Stud. Alcohol, 1, 275, 1966.

9) Mukasa, H. \& Ichinara, T. : Remedy for alcoholism a technique of the double medication of Cyanamide. Kyushu Neuro-Psychiatry, 13, 96, 1964.

10) Usuba, M. : Nitrolime-treatment of Alcoholism. Psychiatr. Neurol. Jap. 58, 93, 1956. 